\title{
Why to ignore alternative therapies in human population?
}

\author{
Shah Murad Mastoi Baloch ${ }^{1}$, Seema Shah Murad², M Ismail Khoso ${ }^{3}$, Tarique Ahmed Maka ${ }^{4}$, Quratulain Saleem ${ }^{5}$, Saleemullah Abro ${ }^{6}$, \\ Wajid Abro ${ }^{7}$, Shah Murad*8 \\ ${ }^{1}$ Professor of Pharmacology, IMDC, Islamabad, Pakistan. \\ ${ }^{2}$ Gynecologist at NMC Karachi Pakistan. \\ ${ }^{3}$ Consultant Physician at CMH Mangla, Pakistan. \\ ${ }^{4}$ ENT Specialist at CMH Mangla, Pakistan. \\ ${ }^{5} \mathrm{AP}$ at Community Medicine Department, Karachi Medical Dental College (KMDC), Karachi, Pakistan. \\ ${ }^{6}$ Assistant Professor of Physiology, Baqai Medical University, Karachi Pakistan. \\ ${ }^{7}$ Research Scholar at Microbiology at BMSI, JPMC Karachi Pakistan. \\ ${ }^{8}$ Pharmacology Deptt: Akbar Niazi Teaching Hospital and IM\&DC, affiliated with SZABMU, Islamabad-PAKISTAN.
}

*Corresponding Author: Shah Murad, Pharmacology Deptt: Akbar Niazi Teaching Hospital and IM\&DC, affiliated with SZABMU, Islamabad-PAKISTAN.

Received date: March 29, 2021; Accepted date: June 10, 2021; Published date: June 14, 2021

Citation: Tarique A Maka, Q Saleem, S Abro, W Abro, S Murad. (2021) Why to ignore alternative therapies in human population. Biomedical Research and Clinical Reviews. 4(2); DOI: 10.31579/2692-9406/060

Copyright:@ 2021 Shah Murad, This is an open-access article distributed under the terms of the Creative Commons Attribution License, which permits unrestricted use, distribution, and reproduction in any medium, provided the original author and source are credited.

\begin{abstract}
After having a meal, cholesterol is digested and absorbed in small intestine then the metabolism and storage occurred in the liver. The cholesterol may be secreted by the liver whenever the requirement of cholesterol is needed by the body. Cholesterol is not present in the food which is derived from the plants. We in this study have compared hypolipidemic effects of Fenugreek, Curcuma longa, and Lemon. Study was conducted at Jinnah Hospital Lahore-Pakistan from January 2016 to May 2016. Ninety hyperlipidemic patients of age group 19 to 70 were included in the study. Exclusion criteria were diabetic, alcoholic additives, hypertensive patients and those whose kidney or liver functions were impaired. Consent was taken from all participants. Their base line lipid profile was taken in biochemistry laboratory of the hospital. They were divided in three groups i.e. 30 patients in each group. Group-I was advised to take $500 \mathrm{mg}$ of Curcuma longa (haldi) mixed in fresh milk without cream, thrice daily for two months. Group-II patients were advised to take 100 grams of Fenugreek leaves mixed with salad in each meal (thrice daily) for the period of two months. GroupIII patients were advised to take $40 \mathrm{ml}$ of fresh lemon juice mixed with $40 \mathrm{ml}$ mineral water thrice daily for two months. They all were advised not to take heavy meal rich with any type of fat like junk food etc. One hour daily brisk walk was advised to all participants. 15 days follow up visit was scheduled for them. After two months their lipid profile was re-determined. When results were compiled and statistically analyzed by applying paired ' $t$ ' test, it revealed that Curcuma longa decreased total cholesterol, TG, LDL cholesterol 16.10, 20.01, and $17.59 \mathrm{mg} / \mathrm{dl}$ respectively. Fenugreek decreased total cholesterol, TGs, and LDL cholesterol 14.70, 17.33, and $17.06 \mathrm{mg} / \mathrm{dl}$ respectively. Lemon in two months therapy decreased total cholesterol, TGs, and LDL cholesterol 15.45, 10.13, and $11.97 \mathrm{mg} / \mathrm{dl}$ respectively. None of the above mentioned herbs raised HDL cholesterol significantly. It was concluded from this research work that Curcuma longa, Fenugreek leaves and Lemon are mild to moderately effective hypolipidemic herbs to lower total plasma cholesterol, triglycerides, and LDL cholesterol but have no potential to raise HDL cholesterol when analyzed.

Keywords: alternative therapies; cholesterol; hypolipidemic
\end{abstract}

\section{Introduction:}

The main etiology of elevated cholesterol in blood is high intake of several saturated fats. Cholesterol are attached or carried by lipoproteins as it cannot travel freely in the blood. Atherosclerotic problems are encountered with enhancement of LDL uptake by monocytes and macrophages $[1,2]$. In the liver, uptake of plasma LDL is mediated via specific LDL receptors, but a scavenger receptor system is employed by macrophages. Plasma LDL must be modified prior to uptake by macrophages. Analysis of the lipid content in the oxidatively modified LDL from hyper lipidemic patients revealed that the level of lysophosphatidylcholine was greatly elevated, and the high level of the lysolipid was shown to impair the endothelium-dependent relaxation of the blood vessels [3-7]. In alllopathy blood lipid levels are normalized by statins, fibrates, niacin and bile acid binding resins (BABRs). All of these allopathy related drugs have low compliance ranges from mild compliance due to metalic taste of BABRs to severe side effects like rhabdomyolysis by fibrates and statins [8]. Due to low compliance and adverse effects of conventionally used hypolipidemic agents, herbal medicines are going to be famous among Physicians, and Cardiologists [9]. Medicinal herbs like Curcuma Longa, Fenugreek, and Lemon contents are being used as mild to moderate hypolipidemic agents. Curcuma Longa commonly known as Haldi in India and Pakistan is used 
to lower plasma lipids, in view of their contents. It contains Curcuminoids (curcumin, demethoxycurcumin, and bisdemethoxycurcumin), turmerone, atlantone, zingiberene, proteins, and resins [10]. Curcumin reduces both the oxidation and circulation of oxidized levels of LDL cholesterol which leads to reduction in the occurrence or treatment of already present atherosclerosis in the subjects [11]. Research has revealed that curcumin from turmeric is an extremely efficient agent in increasing cholesterol uptake by the liver cells [12]. Several independent studies have shown that curcumin increases the expression of cholesterol and lipoprotein receptors on the liver cells [13]. Curcumin also increases cholesterol and bile acids excretion in feces [14]. Additionally, curcumin also increases the amount of ABC (ATP-binding cassette) transporters. These transporters are basically involved in flushing out excess cholesterol from the inside of the macrophages. When the numbers of $\mathrm{ABC}$ transporters are increased on the surface of a macrophage, the deposited cholesterol is effluxes out through these channels again into the blood. Through the blood, it reaches liver where it is metabolized efficiently [15]. The composition of fenugreek includes a large number of chemical components. They include proteins and amino acids, flavonoids, saponins and steroidal saponins, coumarin, lipids, vitamins, minerals, galactomannan fiber and alkaloids, such as trigonelline. Extracts are available standardized to contain 50 percent saponins or 20 percent of the amino acid 4-hydroxyisoleucine [16]. Treatment with fenugreek. Seed powder normalized the enhanced lipid peroxidation and increased susceptibility to oxidative stress associated with depletion of antioxidants [17]. The steroidal saponins (diosgenin, yamogenin, tigogenin and neotigogenin) are thought to inhibit cholesterol absorption and synthesis and hence its potential role in arteriosclerosis [18-21].

\section{Patients \& Method}

The research work was conducted at Jinnah Hospital, Lahore from January 2016 to May 2016 with approval of Research ethics committee of the Hospital. SAMPLE SIZE: Ninety hyperlipidemic patients were selected for research work. CONSENT: Written consent was taken from all patients. Specific Performa was designed for the research work. Hyperlipidemic patients were selected with age range from 19 to 70 years. EXCLUSION CRITERIA: Exclusion criteria were hypertension, hypothyroidism, diabetes mellitus, alcohol addictive patients, peptic ulcer, any gastrointestinal upset, renal impairment, and any hepatic or cardiac problem. GRPOUPING: All patients were divided in three groups (group-I, group-II, group-III), 30 patients in each group. Their baseline lipid profile data were taken and filed in specifically designed Performa, at start of taking medicine, like lipid profile, blood pressure and pulse rate. LIPID PROFILE: Serum lipid profile (total cholesterol, HDL-cholesterol, triglyceride) parameters were determined after a 12 hour overnight fast by standard methods. LDL-cholesterol level was calculated according to the Friedewald's formula. Thirty patients of group-I were advised to take $500 \mathrm{mg}$ of Curcuma longa (haldi) mixed in fresh milk without cream, thrice daily for two months. Group-II patients were advised to take 100 grams of Fenugreek leaves mixed with salad in each meal (thrice daily) for the period of two months. Group-III patients were advised to take 40 $\mathrm{ml}$ of fresh lemon juice mixed with $40 \mathrm{ml}$ mineral water thrice daily for two months. They all were advised not to take heavy meal rich with any type of fat like junk food etc. One hour daily brisk walk was advised to all participants. 15 days follow up visit was scheduled for them. After two months their lipid profile was re-determined. STATISTICAL ANALYSIS: Mean values of the day- 0 and day- 60 of tested parameters (total cholesterol, LDL cholesterol, triglycerides, and HDL cholesterol) \pm SD were taken to be analyzed statistically. SPSS 10 version 2.00.01.10 was used to analyze pretreatment and post treatment values of all parameters. Paired ' $t$ ' test was applied to determine changes in pre and post treatment values. $\mathrm{P}$-value $>0.05$ was considered as non-significant changes in tested parameters, and p-values $<0.01$ were considered as significant changes.

\section{Results}

Hyperlipidemia is abnormally elevated levels of any or all lipids or lipoproteins in the blood. It is the most common form of dyslipidemia (which includes any abnormal lipid levels). When results were compiled and statistically analyzed by using SPSS 10 version 02.00 .01 .10 , it revealed that curcuma longa decreased triglycerides (TG), total cholesterol (TC), and LDL cholesterol of 29 hyperlipidemic patients 20.01, 16.10, and $17.59 \mathrm{mg} / \mathrm{dl}$ respectively. Raise in HDL cholesterol in this group was $03.70 \mathrm{mg} / \mathrm{dl}$. Fenugreek leaves reduced TG, TC, LDL cholesterol of 28 hyperlipidemic patients $17.33,14.70$, and $17.06 \mathrm{mg} / \mathrm{dl}$ respectively. Lemon juice reduced TC, TG, and LDL cholesterol 15.45, 10.13 , and $11.97 \mathrm{mg} / \mathrm{dl}$ respectively. HDL raised $03.55 \mathrm{mg} / \mathrm{dl}$ in this group. Changes in all tested parameters, and their statistical significance are shown in following table.

Three tables are changed

\begin{tabular}{|l|l|l|l|}
\hline $\begin{array}{l}\text { TC at day-0 } \\
271.87 \pm 1.04\end{array}$ & $\begin{array}{l}\text { TC at day-60 } \\
255.77 \pm 2.77\end{array}$ & $\begin{array}{c}\text { Difference in } \\
\mathrm{mg} / \mathrm{d} l 16.10\end{array}$ & $\mathrm{P}$-value $=<0.001$ \\
\hline TG at day-0 & TG at day-60 & & \\
$216.09 \pm 2.43$ & $196.08 \pm 2.45$ & 20.01 & P-value $=<0.001$ \\
\hline $\begin{array}{l}\text { LDL-C at day-0 } \\
179.65 \pm 2.87\end{array}$ & $\begin{array}{l}\text { LDL-C } \text { at day-60 } \\
162.06 \pm 2.51\end{array}$ & 17.59 & P-value $=<0.001$ \\
\hline $\begin{array}{l}\text { HDL-C at day-0 } \\
37.95 \pm 1.45\end{array}$ & $\begin{array}{l}\text { HDL-C } \text { at day-60 } \\
41.65 \pm 1.91\end{array}$ & 3.70 & P-value $=<0.001$ \\
\hline
\end{tabular}

Table 1: Showing parameters values before and after treatment with their statistical significance in group-1(n=29)(Curcuma longa or haldi)

\begin{tabular}{|l|l|l|l|}
\hline TC at day-0 & TC at day-60 & Difference & P-value $=<0.001$ \\
$280.56 \pm 1.06$ & $265.86 \pm 2.65$ & 14.70 & \\
\hline TG at day-0 & TG at day-60 & & \\
$224.87 \pm 1.55$ & $207.54 \pm 1.98$ & 17.33 & P-value $=<0.001$ \\
\hline $\begin{array}{l}\text { LDL-C at day-0 } \\
213.13 \pm 2.78\end{array}$ & $\begin{array}{l}\text { LDL-C } \text { at day-60 } \\
196.07 \pm 1.56\end{array}$ & 17.06 & P-value $=<0.001$ \\
\hline $\begin{array}{l}\text { HDL-C at day-0 } \\
35.19 \pm 2.32\end{array}$ & $\begin{array}{l}\text { HDL-C at day-60 } \\
38.08 \pm 1.67\end{array}$ & 2.89 & P-value $=<0.001$ \\
\hline
\end{tabular}

Table 2: Showing parameters values before and after treatment with their statistical significance in group-2 $(n=28)($ Fenugreek or methi) 


\begin{tabular}{|l|l|l|l|}
\hline $\begin{array}{l}\text { TC at day-0 } \\
258.21 \pm 2.12\end{array}$ & $\begin{array}{l}\text { TC at day-60 } \\
242.76 \pm 1.89\end{array}$ & $\begin{array}{l}\text { Difference } \\
15.45\end{array}$ & P-value $=>0.05$ \\
\hline $\begin{array}{l}\text { TG } \text { at day-0 } \\
246.56 \pm 2.11\end{array}$ & $\begin{array}{l}\text { TG at day-60 } \\
236.43 \pm 2.43\end{array}$ & 10.13 & P-value $=>0.05$ \\
\hline $\begin{array}{l}\text { LDL-C } \text { at day-0 } \\
179.08 \pm 2.87\end{array}$ & $\begin{array}{l}\text { LDL-c at day-60 } \\
167.11 \pm 1.77\end{array}$ & 11.97 & P-value $=>0.05$ \\
\hline $\begin{array}{l}\text { HDL-C at day-0 } \\
36.22 \pm 1.77\end{array}$ & $\begin{array}{l}\text { HDL-C at day-60 } \\
39.77 \pm 1.55\end{array}$ & 3.55 & P-value $=>0.05$ \\
\hline
\end{tabular}

Table 3: Showing parameters values before and after treatment with their statistical significance in group-3 ( $n=29)($ Lemon water)

KEY: All values are written in mean and \pm stands for standard error of mean. $\mathrm{T}-\mathrm{C}=$ serum total cholesterol, $\mathrm{TG}=$ serum triglycerides, $\mathrm{LDL}-\mathrm{C}=$ low density lipoprotein cholesterol, $\mathrm{HDL}-\mathrm{C}=$ high density lipoprotein cholesterol. All parameters pre and post-treatment are measured in mg/d. $\mathrm{n}=$ sample size. P-value $<0.01$ stands for significant change, $\mathrm{P}$-value $>0.05$ stands for non-significant change.

\section{Discussion}

Modern primary care practitioners spend considerable time and effort on preventative medicine. Diagnosing and managing hyperlipidemia as a way to prevent cardiovascular disease (CVD) is a common activity for primary care physicians. According to Centers for Disease Control data from a survey of 1,492 physicians who provide ambulatory care in nongovernment settings, hyperlipidemia is second only to hypertension in the list of the 10 most common chronic conditions that were seen. Cholesterol is a fatty substance that is carried around the body in the blood. The body produces most cholesterol naturally, and it is found in some foods. Lipoproteins carry cholesterol in the blood. The two main types that carry cholesterol to and from cells are called low density lipoproteins (LDL-C) and high density lipoproteins (HDL-C). The lower the density of the lipoproteins the more fats it contains. High density lipoprotein (HDL cholesterol) is called the 'good cholesterol' because it helps to keep cholesterol from building up in the arteries. Low density lipoprotein (LDL cholesterol) is called the 'bad cholesterol' because it is the main source of cholesterol build-up and blockage in the arteries. Statin medication work to reduce this LDL-C. In our results lemon, curcula longa, and Fenugreek proved that significant reduction occurs in TC, TG, LDL cholesterol by using these herbal preparation/mixture. But all of these three herbs have no significant influence on HDL cholesterol. Same results did prove in the study conducted by Wiseman SA et al [22]. Who described that pectin present in these three herbs inhibit enterohepatic circulation of bile acids and excrete cholesterol in feces. Flavenoids present in Fenugreek are responsible for inhibition of cholesterol synthesis [23]. Gidez LI et al [24]. stated that herbal medications have more than one or two mechanism to balance plasma lipids in hyperlipidemic patients. Bingham SA et al [25]. stated that the major reasons for hypercholesterolemia in today's world are obesity, consuming high fat food, diabetes and having a family history of high cholesterol. This disorder is reported to affect a large number of people all across the world and is one of the leading causes of death as well. Cholesterol is reduced in the body by managing weight and diet. Regular exercise, lesser consumption of fatty foods, more consumption of fruits and vegetables help in ameliorating the symptoms of hypercholesterolemia. However, in most cases, medications also known as anti-hypertensive and anti-cholesterol drugs are also required, especially in chronic cases. There are several problems associated with medications though and people are now switching towards newer and less toxic therapies to control and reduce cholesterol levels in the body. Several natural herbs, supplements and food products are known to maintain healthy cholesterol levels and reduce cholesterol in mild hypercholesterolemia. These therapies, if opted for, help in preventing the disorder but are less helpful in chronic cases of this disease. In an experiment [26], controlled dosing of turmeric was used to feed hypercholesterolemic rabbits and the effects on LDL oxidation was analyzed. It was found that turmeric extracts efficiently and quickly reduced the levels of cholesterol in the blood along with the incidences of atherosclerosis with time. The reason for these therapeutic effects, when analyzed, was found to be the preventive action of turmeric on the oxidation of LDL cholesterol. Mattern T et al [27], have also explained same important mechanism of action of Turmeric that oil of these seeds inhibits enterohepatic circulation causing biosynthesis of bile acids instead of cholesterol by hepatocytes. The results obtained from research work conducted by Geleijnse JMet al [28], revealed that all extracts of the fenugreek exhibit antioxidant activity. These findings suggest that the fenugreek extracts could act as potent source of antioxidants. Magee E et al [29]. Mentioned that many herbs and their constituents have potential to reduce total plasma cholesterol LDL cholesterol, and triglycerides but they do not raise HDL cholesterol because it needs special plasma proteins as lipoproteins responsible for structural and functional integrity of HDL particles. The fact that hyperlipidemia is a strong risk factor for CVD is well established. Hyperlipidemia refers to elevated cholesterol, elevated TG or both. The problem can be due solely to hereditary factors, but more commonly it is an acquired condition. Physicians need to know the major categories of dyslipidemia and to have a well-reasoned action plan for dealing with each one, including knowing when to refer a case to a lipidology specialist. It is the purpose of this paper to review the categories of hyperlipidemia, the current treatment recommendations and the current controversies and unresolved questions [30-36].

\section{References}

1. Suther TR, Fankir TG, Manzoor AD, Wiseman, S. A. (2012) A single dose of tea with or without milk increases plasma antioxidant activity in humans. Ind J. Nutr. 54:87-92.

2. Walker TT, Eros PL, Strain, J. J. (2013) The ferric reducing ability of plasma (FRAP) as a measure of "antioxidant power": the FRAP assay. Anal. Biochem. 239:70-76.

3. Wersoz DA, Rozepa LL, Thermost TT, Sanders, T. A. \& Wiseman, H. (2015) Flavonoids protect against oxidative damage to LDL in vitro: use in selection of a flavonoid rich diet and relevance to LDL oxidation resistance ex vivo. Free Rad. Res. 33:419-426.

4. Rohalo M, Terhto P, Ferro-Luzzi, A. (2012) In vivo antioxidant effect of green and black tea in man. J. Clin. Nutr. 50:28-32.

5. LM Jekar, S. A. \& Bouwens, L. C. (2011) The chemistry of tea flavonoids. Crit. Rev. Food Sci. 37:693-704.

6. Thakola M, Herus M, Thorpe, G. (2014) Atherosclerosis: newer viewpoints. Pk Med. J.

7. Yahama C, Ito, T., Yoshida, H., Ayaori, M., Nishiwaki, M., Yonemura, A., Hara, Y. \& Nakamura, H. (2014) Conventional hypolipidemic medicines and their compliance. Libyan J. Nutr. 66:261-266.

8. Firisa JH, Solvoll, K. \& Foss, O. P. (2014) Tea consumption. Relationship to cholesterol, blood pressure, and coronary and total mortality. Prev. Med. 21:546-553. 
9. Sesso, H. D., Gaziano, J. M., Buring, J. E. \& Hennekens, C. H. (2014) Hypolipidemic constituents in herbs. J. Epidemiol. 149:162-167.

10. Hodgson, J. M., Puddey, I. B., Croft, K. D., Burke, V., Mori, T. A., Caccetta, R. A. \& Beilin, L. J. (2014) Chemical contents of Curcuma Longa. J. Nutr. 71:1103-1107.

11. Klatsky, A. L., Friedman, G. D. \& Armstrong, M. A. (2012) Curcuma longa affects LDL-oxidation. Med. J. Epidemiol. 132:479-488.

12. Hertog, M. G., Sweetnam, P. M., Fehily, A. M., Elwood, P. C. \& Kromhout, D. (2013) Antioxidant flavonols and ischemic heart disease. Sr J. Med. 65:1489-1494.

13. Kono, S., Shinchi, K., Ikeda, N., Yanai, F. \& Imanishi, K. (2013) Miraculos hypolipidemic herb: CURCUMA LONGA. Japan. Prev. Med. 21:526-531.

14. Fogelman, A. M., Shechter, I., Seager, J., Hokom, M., Child, J. S. \& Edwards, P. A. (2015) Curcuma longa inhibits enterohepatic circulation. J Sur \& Med Ind. 77:2214-2218.

15. Lowry, O. H., Rosenbrough, N. J., Farr, A. L. \& Randall, R. J. (2013) ATP-binding cassette transporter and efflux of lipids. J. Biol. Chem. 193:265-275.

16. keda, I., Imasato, Y., Sasaki, E., Nakayama, M., Nagao, H., Takeo, T., Yayabe, F. \& Sugano, M. (2013) Chemical compounds found in Fenugreek seeds. J Bioch. 1127:141-146.

17. Yang, C. S. \& Landau, J. M. (2014) Handling LDL oxidation with herbal medicine. J. Cl. Nutr. 130:2409-2412.

18. Keli, S. O., Hertog, M. G., Feskens, E. J. \& Kromhout, D. (2014) Dietary flavonoids, antioxidant vitamins, and incidence of stroke. J. Med Sc. 156:637-642.

19. Mukhtar, H. \& Ahmad, N. (2014) Metalic Chelation by Curamin. J Cl Med. 71:1698S-1702S

20. Princen, H. M., van Duyvenvoorde, W., Buytenhek, R., Blonk, C., Tijburg, L. B., Langius, J. A., Meinders, A. E. (2014) Phenolic compond rich foods for cure of CAD. J Health Med Ethop. 18:833-841.

21. Hertog, M. G., Feskens, E. J., Hollman, P. C., Katan, M. B. \& Kromhout, D. (2015) Lemon Juice for treating hyperlipidemia and CAD. J Ind Med. 42:1007-1011.

22. Wiseman, S. A., Balentine, D. A. \& Frei, B. (2014) Antioxidant potential of pectin present in herbs. 37:705-718.

23. Tijburg, L. B., Mattern, T., Folts, J. D., Weisgerber, U. M. \& Katan, M. B. (2014) Favonoids and cardiovascular disease: a review. J Biol Pk. 37(2):771-785.
24. Gidez, L. I., Miller, G. J., Burstein, M., Slagle, S. \& Eder, H. A. (2015) MOA of hypolipidemic herbs. J of Med Therapy. 23(4):206-223.

25. Bingham, S. A., Vorster, H., Jerling, J. C., Magee, E., Mulligan, A., Runswick, S. A. \& Cummings, J. H. (2015) Obesity, hypercholestrelemia, metabolic syndrome and options of their cure. Med J Prev Med. 78(3):41-55.

26. Reaven, P. D. \& Witztum, J. L. (2013) Oxidized low density lipoproteins in atherogenesis: role of dietary modification. $\mathbf{J}$ Ethop Med. 16(6):51-71

27. Mattern T, Witztum JL, Weisgerber UM. (2012) Turmic seeds oil interupts enterohepatic circulation of Bas. J. Lipid Res. 53:2490-2514.

28. Geleijnse, J. M., Launer, L. J., Hofman, A., Pols, H. A. \& Witteman, J. C. (2014) How fenugreek is antioxident? Food Sc. 159:2170-2174.

29. Magee, E., Mulligan, A, Constrv YL. (2014) Consumption of Foods Rich in Flavonoids Is Related to a Decreased Cardiovascular Risk. J. Med Nutr. 134:23-26.

30. Doorse B, Yahama C, Ito, T., Yoshida, H., Ayaori, M., Nishiwaki, M., Yonemura, A., Hara, Y. \& Nakamura, H. (2014) Conventional hypolipidemic medicines and their compliance. Libyan J. Nutr. 66:261-266.

31. Therwov YT, Firisa JH, Solvoll, K. \& Foss, O. P. (2014) Tea consumption. Relationship to cholesterol, blood pressure, and coronary and total mortality. Prev. Med. 21:546-553.

32. Morasa GT, Sesso, H. D., Gaziano, J. M., Buring, J. E. \& Hennekens, C. H. (2014) Hypolipidemic constituents in herbs. J. Epidemiol. 149:162-167.

33. Croft, K. D., Burke, V., Mori, T. A., Caccetta, R. A. \& Beilin, L. J. (2014) Chemical contents of Curcuma Longa. J. Nutr. 71:1103-1107.

34. Yulagr RE, Klatsky, A. L., Friedman, G. D. \& Armstrong, M. A. (2012) Curcuma longa affects LDL-oxidation. Med. J. Epidemiol. 132:479-488.

35. Jihuyt MM, Hertog, M. G., Sweetnam, P. M., Fehily, A. M., Elwood, P. C. \& Kromhout, D. (2013) Antioxidant flavonols and ischemic heart disease. Sr J. Med. 65:1489-1494.

36. Qulvina O, Kono S, Shinchi K, Ikeda N, Yanai F \& Imanishi K. (2013) Miraculos hypolipidemic herb: CURCUMA LONGA. Japan. Prev. Med. 21:526-531.

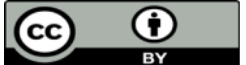

This work is licensed under Creative Commons Attribution 4.0 License

To Submit Your Article Click Here: Submit Manuscript

DOI: $10.31579 / 2692-9406 / 060$
Ready to submit your research? Choose Auctores and benefit from:

*ast, convenient online submission
* rigorous peer review by experienced research in your field
*apid publication on acceptance
* unthors retain copyrights
* immediate, unrestricted online access

At Auctores, research is always in progress.

Learn more www.auctoresonline.org/journals/biomedical-research-andclinical-reviews- 